\title{
KEKUATAN KEPEMIMPINAN YANG MELAYANI DALAM MANAJEMEN KONFLIK PADA KEUSKUPAN TNI/POLRI
}

\author{
Oleh Rofinus Neto Wuli
}

\begin{abstract}
Abstrak
Penelitian ini bertujuan menemukan pemaknaan mendalam kekuatan kepemimpinan pelayan dalam manajemen konflik di Keuskupan TNI/Polri. Penelitian bertema "Kekuatan Kepemimpinan Pelayan Dalam Manajemen Konflik Pada Keuskupan TNI/Polri" ini menggunakan metode kualitatif dengan pendekatan ethnography yang dihimpun berdasarkan observasi, wawancara, dan Focus Group Discussion dengan para prajurit, perwira, purnawirawan, dan Pegawai Negeri Sipil di lingkungan TNI/Polri beragama Katolik yang merupakan warga Keuskupan TNI/Polri. Hasil penelitian menunjukkan: 1) Dalam perspektif warga Keuskupan TNI-Polri/Ordinariatus Castrensis Indonesia (OCI), konflik adalah sebuah keniscayaan di dalam kehidupan manusia. 2) Spirit pelayanan yang dihayati warga OCI bersumber pada nilai universal Kristiani seperti kasih, pelayanan, kelembutan, kebenaran, keadilan, damai sejahtera, harmoni, belarasa, dan solidaritas. Nilai-nilai ini secara efektif dapat ditransformasi anggota OCI dalam kehidupan bersama. 3) Penerapan manajemen konflik di OCI merujuk pada ajaran Katolik yang menempatkan hukum cinta kasih, persaudaraan dan pengampunan sebagai yang utama. 4) Manajemen Konflik berbasis kepemimpinan pelayan sangat kuat dan efektif dalam meresolusi konflik karena digerakan oleh spirit Iman yang berkualifikasi melayani dalam damai. 5) Kepemimpinan yang ideal dalam menyelesaikan konflik adalah kepemimpinan pelayan melalui pendekatan kemanusiaan yang diyakini dapat menghasilkan rekonsiliasi dan damai yang berkelanjutan. Kebaruan penelitian ini terletak pada kepemimpinan pelayan dapat menjadi basis yang kuat dalam mengelimininasi konflik, serta memiliki elemen utama sangat penting dan strategis dalam manajemen konflik yang bermuara pada rekonsiliasi damai. Melalui "Dinamika Manajemen Konflik Berbasis Servant Leadership", peneliti menemukan empat tahapan me-manage konflik . Pertama, mengusahakan adanya nilai saling percaya, pengampunan, empati, dan kerendahan hati dari pihak yang berkonflik. Kedua, pihak yang berkonflik memastikan pengampunan, saling percaya, empati dan rendah hati dilakukan secara serentak, bekerja sama, dibiasakan, dan dipraktikkan dalam hidup sehari-hari. Ketiga, pihak yang berkonflik menjalankan kepemimpinan yang melayani sebagai pengikat empat elemen tersebut. Keteladanan kepemimpinan pelayan dengan pendekatan kemanusiaan dapat menggerakkan pihak yang berkonflik (inspirasi dan teladan) untuk memiliki empat keutamaan tersebut. Keempat, melakukan manajemen konflik berbasis kepemimpinan pelayan. Empat elemen utama Servant Leadership berkekuatan positif akhirnya menjadi satu kesatuan utuh yang mewujudkan rekonsiliasi dan damai berkelanjutan sebagai muara dari manajemen konflik.
\end{abstract}

Kata kunci: Konflik, Manajemen Konflik, Rekonsiliasi dan Damai, Kepemimpinan Pelayan.

\section{PENDAHULUAN}

$\mathrm{K}$ onflik adalah fenomena sosial yang umum kita alami setiap hari. Tidak ada orang yang hidup bebas dari konflik. Ada konflik antar- saudara, antar agama, antara perusahaan dengan karyawan, dan konflik antara dua kelompok masyarakat, dan lain-lain. Banyak tenaga dan pikiran yang tercurah untuk menyelesai konflik, atau minimal agar tidak bereskalasi menjadi aksi kekerasan. Tidak semua upaya 
penyelesaian konflik berhasil maksimal lantaran pihak yang berkonflik atau penengah dalam sebuah konflik memiliki keterbatasan pengetahuan tentang manajemen konflik. Dalam manajemen konflik ada proses yang disebut resolusi konflik, yakni mengupayakan konflik berbuah perdamaian.

Pentingnya manajemen konflik, resolusi konflik, dan rekonsiliasi menuju terciptanya perdamaian pernah menjadi bahan penelitian penulis pada masyarakat Ngada. Kekuatan yang dimiliki orang Ngada dalam menyikapi, menghadapi, serta menyelesaikan konflik adalah terintegrasinya nilai budaya (adat tanah Ngadha) dan nilai-nilai-nilai keagamaan (Katolik). Budaya Ngada dengan filosofi "modhe nee soga woe meku nee doa delu" sejalan dengan spirit rekonsiliasi dan nilai cinta kasih serta pengampunan dalam ajaran Katolik yang telah menyatu dengan masyarakat Ngada (Neto Wuli, 2015:3).

Secara tradisional, konflik diartikan sebagai pertentangan antara dua kelompok kepentingan demi tujuan tertentu. Adalah Johan Galtung yang memperkenalkan pemahaman komprehensif tentang konflik. Galtung membedakan konsep perdamaian positif dan perdamaian negatif. Galtung memperluas cakupan konflik pada kondisi pra-konflik, seperti budaya damai. Budaya damai yang abadi (eternal peace) yang tidak memungkinkan adanya konflik juga terdapat dalam konflik (Galtung, 2007: 14-16).

Pendekatan teori-teori manajemen mengatakan manajemen konflik berbasis kepemimpinan memiliki pengaruh besar dalam mencegah adanya konflik, mempengaruhi timbulnya konflik dan juga lebih jauh menyelesaikan konflik (Fahmi, 2016: 296). Kepemimpinan dapat mempengaruhi cara pandang ataupun perlakuan terhadap konflik dalam komunitas. Manajemen konflik berbasis kepemimpinan dalam komunitasnya sangat menentukan penyelesaian konflik: apakah konflik berbuah produktif atau bersikap kontraproduktif. Misalnya, penelitian Fadima Cinar dan Ayca Caban (2012: 197-206), yang menyatakan bahwa sebuah organisasi hanya dapat bertahan dalam keadaan konflik jika di bawah pengaruh ataupun penentuan dari kepemimpinan dalam organisasi. Hasil penelitian keduanya diabstraksikan dari adanya program konversi kesehatan di Turki, yang dimulai pada 2008.

Blake dan J Mouton (1964) melalui studinya tentang kepemimpinan menemukan bahwa manajemen konflik berbasis kepemimpinan sangat penting dalam penyelesaian konflik. Seseorang dapat menggunakan paksaan, konfrontasi, kompromi, menarik diri, ataupun cara akomodatif dalam menyelesaikan konflik. Thomas dan Ralph H. Kilmann (1974) yang menekankan gaya kolaboratif dalam menyelesaian konflik. Seseorang dapat menggunakan cara kompetisi, kolaborasi, kompromi, menghindar, dan akomodasi. Namun, terdapat sejumlah akademisi atau teoretisi yang menganjurkan manajemen konflik berbasis kepemimpinan kuat (strong leadership) untuk mengelola konflik. Ganta dan Manukonda (2014) mendefinisikan kepemimpinan yang kuat sebagai kepemimpinan di mana seseorang memiliki kemampuan untuk mempengaruhi atau mengubah nilai, kepercayaan, perilaku dan sikap orang lain .

Dalam konteks ini, maka pendapat alternatif lainnya jika dikaitkan dengan manajemen konflik berbasis kepemimpinan dari Robert K. Greenleaf menjadi menarik. Greenleaf (1970: 3) menulis sebuah esai menarik berjudul "Servant as a leader." Dalam hubungannya dengan konflik, manajemen konflik berbasis kepemimpinan yang 
melayani berhubungan erat dengan manajemen pelayanan dari seorang pemimpin pelayan.

Gagasan genial dari Greenleaf ini akan sangat menarik ketika dihubungkan dengan pelayanan Keuskupan Umat Katolik di Lingkungan TNI dan Polri (Latin: Ordinariatus Castrensis Indonesia/OCI). Dalam perspektif manajemen, Keuskupan Umat Katolik di Lingkungan TNI/Polri sebagai organisasi bertujuan mendidik mental rohani para prajurit TNI/Polri yang beragama Katolik untuk bermental tangguh dan setia mengabdi Negara dalam keadaan apapun. Organisasi ini bertujuan menerjemahkan nilai-nilai kekatolikan dalam konteks TNI/Polri sehingga dapat membantu para prajurit untuk mengolah konflik baik secara internal, baik dalam insititusi TNI/Polri maupun dalam organisasi Keuskupan Umat Katolik di Lingkungan TNI-Polri (OCI).

Pilihan gaya kepemimpinan OCI ini akan bertemu dengan gagasan pemimpin yang kuat (strong leadership) dalam insitusi TNI/Polri. Institusi TNI/Polri menekankan gaya kepemimpinan hierarkis-dominan, mengutamakan kekuatan dan wibawa pemimpinnya dengan pola senioritas atau ketaatan structural untuk mendukung terwujudnya profesionalisme keprajuritan. Para pimpinan diberikan keistimewaan dalam merencanakan, menyelenggarakan, dan mengawasi pelaksanaan pembinaan mental prajurit. Manajemen konflik berbasis kepemimpinan melayani diterapkan di Keuskupan TNI/Polri dalam lingkungan TNI/Polri yang cenderung menerapkan pola kepemimpinan hierarkis-struktural dengan standart operational procedure (SOP) berdasarkan sistem komando. Pendekatan stabilitas diutamakan dalam penyelesaian konflik.

Penelitian ini akan menunjukkan sebaliknya bahwa manajemen konflik berbasis kepemimpinan yang melayani sangat berpengaruh kuat dalam melakukan resolusi konflik, bahkan menunjang aspek produktivitas organisasi. Pendekatan yang digunakan dalam konflik adalah pendekatan persuasif, di mana setiap anggota diberdayakan atau memiliki tanggung jawab dalam penyelesaian konflik. Untuk menjaga adanya budaya damai yang abadi tidak ditunjukkan (hanya) melalui doktrin-doktrin yang menuntut kepatuhan. Di dalam pelayanan, pemberdayaan, dan cinta kasih yang ditunjukkan dalam ajaran terutama dalam teladan hidup sehari-hari, basis kepemimpinan yang melayani dapat secara kuat mempengaruhi organisasi. Melalui penelitian terhadap pelaksanaan manajemen konflik berbasis kepemimpinan melayani di OCI akan dibuktikan bahwa di dalam pelayanan, kelembutan, kasih, dan pengampunan (pemaafan), konflik dapat diatasi. Bahkan yang terjadi adalah basis kepemimpinan melayani dapat mewujudkan cakupan komprehensif konflik yakni terwujudnya budaya damai (culture of peace).

Penelitian tentang kekuatan kepemimpinan yang melayani dalam manajemen konflik ini relevan dengan tugas peneliti yang saat ini menjadi dosen pengampu mata kuliah Manajemen Organisasi, dan mata kuliah Kebijakan Publik yang beberapa materi pembelajarannya meliputi tema-tema: Kepemimpinan yang Melayani (Servant Leadership), Manajemen Paroki, Manajemen Konflik, dan lain-lain di Semester 5 dan 6 Prodi "Pendidikan dan Pengajaran Agama Katolik" pada Sekolah Tinggi Pastoral Atma Reksa Ende. 


\section{KAJIAN PUSTAKA}

\section{Konflik}

Kazimoto (2013) menyatakan konflik itu inheren dan niscaya dalam kehidupan manusia. Konflik yang didalami pada bagian ini adalah pemahaman konflik secara komprehensif menurut Galtung. Konflik tidak hanya dimengerti sebagai pertentangan antara dua pihak karena memiliki tujuan, kepentingan, latar belakang yang berbeda (konflik dalam pengertian negatif).

Konflik-konflik ini harus dikelola melalui manajemen dan resolusi konflik serta rekonsiliasi untuk mencapai tatanan kehidupan bersama yang penuh damai. Johan Galtung (2007: 14-16) membedakan antara perdamaian positif (positive peace) dan perdamaian negatif (negative peace). Pengertian ini meluaskan cakupan konflik. Cakupan konflik bukan hanya ketika konflik sementara berlangsung (in case or happening), tetapi pra-kondisi atau sebelum konflik terjadi (what happened before conflict).

\section{Manajemen Konflik}

Konflik harus diolah dan diselesaikan dengan baik, agar tidak berakhir dengan kekerasan. Pengolahan konflik disebut sebagai manajemen konflik. Resolusi konflik sebagai proses penyelesaian konflik menuju terciptanya budaya damai. Menurut Thakore (2013), manajemen konflik adalah upaya mengelola perselisihan, atau untuk menghindari eskalasi konflik. Resolusi konflik mengacu pada penanganan atau penghapusan penyebab konflik. Manajemen konflik akan mengacu pada strategi dan pengelolaan konflik serta strategi dan pendekatan untuk menyelesaikannya. Konflik dalam kehidupan setiap hari bersikap netral, tergantung dari bagaimana diberi isi di tengah perbedaan. Ia bersifat negatif jikalau diselesaikan dengan kekerasan. Konflik bersifat positif jika menciptakan saling pengertian dan perdamaian. Karena itu konflik harus diolah dan diselesaikan dengan baik, agar tidak berakhir dengan kekerasan. Pengolahan dan penyelesaian konflik ini disebut sebagai manajemen konflik.. Resolusi konflik pada umumnya diartikan sebagai upaya yang dilakukan untuk menyelesaikan konflik dengan cara mencari kesepakatan antara para pihak yang terlibat dalam konflik. Resolusi konflik tidak mencapai kompromi semu, tetapi berusaha mencapai budaya damai yang berkelanjutan.

\section{Budaya Damai}

Ikhtiar membangun "budaya damai" (culture of peace) bukan hanya semata-mata berupa konsep teoretis saja, melainkan sebuah keseluruhan realitas yang dihayati, sebagai sebuah cara hidup yang dipraktikkan dalam berbagai tingkat relasi yang berbeda-beda dalam sebuah komunitas. Budaya damai menuntut suatu perwujudan konkret. Konsep dan pemahaman damai bukan sekadar tiadanya perang dan kekerasan. Damai berarti realisasi keadilan, di mana ada penghargaan terhadap hak-hak asasi dan kemerdekaan manusia. Mewujudkan perdamaian berarti bekerja dan mengupayakan agar relasi antara orang, kelompok, dan lembaga-lembaga (sosial, politik, ekonomi, budaya, pendidikan) bisa memajukan kesejahteraan dan pengembangan setiap orang, dan karenanya memperkaya inti budaya dari setiap orang maupun komunitas. 
Pemahaman ini sejalan dengan konsep perdamaian Johan Galtung (1995). Perdamaian pertama-tama adalah tidak adanya kekerasan langsung (perdamaian negatif). Kekerasan dan konflik sesungguhnya merupakan lawan dari kondisi damai. Menurut Galtung, jenis perdamaian ini terlalu sempit dan tidak mencukupi, karena itu perlu dikembangkan konsep perdamaian yang luas, yaitu tidak adanya kekerasan struktural (sistem dominasi), yang disebut juga sebagai perdamaian positif karena dibatasi secara positif oleh keadilan sosial. Cakupan keadilan sosial Galtung tidak hanya menyangkut distribusi barang-barang atau sumber-sumber daya dan persamaan dalam hukum, namun terutama redistribusi kekuasaan, kewenangan atas distribusi sumber-sumber daya (ekonomi, sosial politik, budaya dan pengetahuan /informasi).

\section{Rekonsiliasi}

Rekonsiliasi secara etimologis berasal dari bahasa Latin: re-consilliare; re (lagi, sekali lagi), consiliare: mengumpulkan. Namun, kata forsoning dalam bahasa Swedia lebih menjelaskan term ini, yakni penegakkan kembali damai dan solidaritas di antara orang-orang yang terbagi, ataupun dalam agama. Rekonsiliasi berurusan dengan pertanyaan: bagaimana menciptakan budaya damai di tengah suatu tatanan yang pernah berkonflik dengan menggunakan kekerasan. Rekonsiliasi menyatukan persahabatan, atau bersahabat lagi setelah sekian lama terputus karena konflik. John P. Lederach (1996: 62) menggunakan istilah rekonsiliasi sebagai satu unsur utama dalam menangani konflik dan membangun masyarakat yang terpecah dewasa ini. Ia mengartikan rekonsiliasi sebagai proses pembangunan relasi. Rekonsiliasi menyediakan fokus dan lokus yang cocok untuk setiap proses penegakkan perdamaian dan bersifat mendasar terhadap kesinambungan perdamaian tersebut.

\section{Manajemen Konflik Berbasis Kepemimpinan}

"Pemimpin" berbeda artinya dengan "kepemimpinan". Pemimpin adalah sosok atau orang yang memimpin suatu (organisasi, kelompok) dan memiliki sejumlah kewenangan spesifik, serta memiliki akses lebih dekat pada pengambilan keputusan dari para anggotanya. Menurut Gary Yukl (2006: 7), kepemimpinan adalah "proses mempengaruhi orang lain untuk memahami dan menyetujui apa yang perlu dilakukan dan bagaimana melakukannya, dan proses memfasilitasi upaya individu dan kolektif untuk mencapai tujuan bersama."

Adapun teori utama (grand theory) yang dipakai dalam penelitian ini adalah teori R.R. Blake dan J. Mouton sebagaimana dikutip Wirawan (2009: 138-139) karena keduanya memperkenalkan manajemen konflik berbasis kepemimpinan. Keduanya menemukan bahwa dalam melakukan manajemen konflik yang mencapai perhatian pada anggota dan keluaran konflik, seseorang dapat melakukan lima pendekatan: 1) memaksa, 2) konfrontasi (confronting), 3) kompromi (compromising), 4) menarik diri (withdrawal). Teori utama lain yang digunakan dalam penelitian ini adalah teori Kennett W. Thomas dan Ralph Kilmann (1974) yang mengembangkan manajemen konflik berbasis kepemimpinan berdasarkan dimensi kerja sama dan keasertifan. Dalam melakukan manajemen konflik terdapat dua hal yang cenderung dipilih, yakni kerja sama sebagai upaya memuaskan orang lain jika menghadapi konflik atau upaya memuaskan diri sendiri jika menghadapi konflik. Keduanya coba menengahi dua pilihan tersebut dengan menekankan pendekatan kolaboratif di mana mencari alternatif lain yang bukan tujuan kedua belah pihak. Jalan keluar yang dicari memuaskan kedua 
belah pihak. Manajemen konflik berbasis kepemimpinan yang berciri kolaboratif akan berusaha memakai negosiasi yang dapat mengundang kreativitas dan inovasi. Kolaborasi membuka hubungan interpersonal, meningkatkan kreativitas dan inovasi, dan mengembangkan iklim organisasi yang lebih terbuka, percaya, dan berintegritas.

\section{Kepemimpinan yang Melayani sebagai Basis Manajemen Konflik}

Robert K. Greenleaf adalah orang yang memopulerkan teori kepemimpinan yang melayani (Servant Leadership). Dia dianggap sebagai pelopor pendekatan servant leadership modern (Susanto, 2020:xxxviii) . Namun konsep kepemimpinan yang melayani diyakini telah diajarkan oleh Yesus Kristus, pembawa ajaran kekristenan sejak awal masehi (Blanchard \& Broadwell, 2018: 1-2). Pada 1970, Greenleaf menulis sebuah esai berjudul "Servant as a Leader." Kualifikasi dari seorang pemimpin pertama-tama adalah kemauannya untuk melayani orang lain, bukan memerintah orang lain. Pemimpin tidak terbatas pada tugas instruksional, tetapi memberi dirinya secara total kepada organisasi yang dipimpinnya.

Dalam tafsirannya terhadap konsep kepemimpinan Greenleaf, Stephen Corey sebagaimana dikutip Numberi (2011: 193) mengafirmasi, bahwa organisasi yang membiasakan kepemimpinan yang melayani akan membiasakan pula kompetisi untuk saling melayani. Kepemimpinan ini, demikian Corey, sangat mulia karena memberdayakan sebanyak mungkin orang, mengundang banyak orang untuk berpartisipasi dalam organisasi. Sementara Larry Spears (dalam Blanchard \& Broadwell, 2018: 15-17) mengatakan pemimpin yang melayani memiliki 10 karakter nilai: 1)mendengarkan, 2)berempati, 3)berkemampuan menyembuhkan, 4)pemimpin yang memiliki kesadaran diri, 5)persuasif, 6)cerdas melakukan konseptualisasi, 7)visioner, 8)kapabel untuk melayani, 9)membangun /memberdayakan orang lain, dan 10) membangun komunitas.

\section{METODE PENELITIAN}

\section{Waktu dan Tempat Penelitian}

Penelitian ini mulai dilakukan sejak awal Mei 2014 dan mulai intensif dilakukan sejak Oktober 2017 hingga Mei 2019. Tempat penelitian dilakukan di wilayah Keuskupan Umat Katolik di Lingkungan TNI/Polri, seperti ke Komando Daerah Militer (Kodam), Kepolisian Daerah (Polda), Pangkalan Laut (Lanal) dan Pangkalan Udara (Lanud), untuk mengumpulkan data berupa pengamatan, wawancara, dan Focus Group Discussion (FGD) dan dokumentasi. Karena Keuskupan TNI-Polri menjangkau wilayah Indonesia, maka observasi dan penelitian tersebar di seluruh Indonesia.

\section{Latar Penelitian}

Budaya yang ada dalam penelitian adalah campuran dialektis budaya keprajuritan insitusi TNI/Polri dan budaya Katolik, serta tradisi pribadi peneliti. Budaya ini menjadi latar belakang yang mempengaruhi subjek yang diteliti dan tindakan penelitian subjek peneliti. Pemikir filosof Juergen Habermas (1993: 192), terinspirasi dari Edmund Husserl menyebut latar ini sebagai "dunia kehidupan" (Lebenswelt). Dunia kehidupan dalam penelitian ini yang akan dibeberkan adalah Keuskupan TNI/Polri di mana penelitian dilakukan. Lebenswelt dapat dibayangkan sebagai horizon yang memiliki 
batas-batas yang menentukan sampai mana pengamat berdiri. Jika berbicara tentang OCI, maka tema ini membatasi semesta penelitian dan sekaligus mengartikulasikan situasi penelitian. Lebenswelt OCI sebagai pengetahuan latar-belakang, yang membuat penelitian ini tidak berpijak pada kekosongan, melainkan memiliki latarnya.

OCI sebagai organisasi yang didirikan dalam konteks pembinaan mental TNI/Polri agar dapat menginternalisasi nilai-nilai ajaran agama, Pancasila, Sapta Marga, Sumpah Prajurit dan Tri Brata dalam rangka menciptakan anggota TNI/Polri sekaligus penganut agama Katolik yang tangguh di lapangan sembari memiliki ketahanan moral yang kuat. Agama Katolik sebagai salah satu agama yang diakui di Indonesia mendidik anggota TNI/Polri (beragama Katolik) supaya memiliki jati diri religius, bermoral luhur, dan memiliki keutamaan-keutamaan nilai kepahlawanan atau dalam versi Uskup Militer pertama, Mgr. Albertus Soegjapranata SJ: “100 \% Katolik 100 \% Indonesia."

\section{Desain Penelitian}

Metode penelitian dalam penulisan ini adalah metode kualitatif. Metode kualitatif selalu memusatkan pada kualitas makna (hakikat dan esensi) dari fenomena atau kasus yang diteliti (Buku Pedoman Penulisan Karya Ilmiah UNJ , 2018). Karena itu, dalam penelitian ini dilakukan pendekatan dengan partisipan pengumpulan data (asumsi epistemologis), menggunakan gaya naratif, dan bekerja sesuai logika induktif. Berdasarkan desain penelitian kualitatif dari Creswell (2012) peneliti melakukan peneltian ini melalui tahapan: 1) persiapan penelitian; 2) menentukan fokus, sub fokus, dan rumusan masalah; 3) kajian teoritis; 4) pengumpulan data; 5) analisis data; 6)penyajian data hasil penelitian; dan 7) penyajian laporan penelitian.

Observasi penelitian menggunakan metode pengumpulan data secara kualitatif (Herdiansyah, 2015) yaitu dengan mengamati secara langsung objek yang menjadi kajian observasi yakni para prajurit TNI dan Polri beragama Katolik yang bernaung dalam wadah OCI. Dengan menggunakan metode observasi partisan di mana ada kesadaran bahwa "Observasi sebagai sebuah proses penggalian data yang dilakukan langsung oleh peneliti sendiri, bukan oleh asisten peneliti atau orang lain, dengan cara melakukan pengamatan secara mendetail terhadap objek observasi" (Creswell, 2012), maka untuk kepentingan penelitian ini saya telah melakukan observasi secara langsung dengan melakukan kunjungan pastoral sambil melakukan pelayanan rohani kepada para Prajurit TNI/Polri, PNS di lingkungan TNI/Polri beserta keluarganya sebagai warga OCI, dalam rentang waktu yang cukup lama, sejak kunjungan pelayanan Retret Prajurit TNI-Polri di Kodam IV/Diponegoro bertempat di Rumah Retret Griya Asisi Bandungan Ambarawa Semarang, 14-16 Oktober 2014 hingga Minggu, 5 Mei 2019, saat kunjungan pelayanan bagi Prajurit OCI yang bertugas di Pos Lintas Batas Negara (PLBN) RIMalaysia di Entikong. Observasi penelitian ini dibuat dengan lokus (tempat) di seluruh wilayah Indonesia.

Untuk mengumpulkan materi penelitian, dilakukan wawancara dan FGD dengan para narasumber yang merupakan prajurit dan perwira TNI/Polri serta PNS di sejumlah Kodam/Garnisun, Polda, Lantamal dan Lanud di seluruh Indonesia. Pemilihan lokasi penelitian dilakukan berdasarkan keterwakilan wilayah. Untuk wilayah Indonesia Barat diwakili Garnisun Tetap I Jakarta dilakukan pada 7 Desember 2018 dan Garnisun Tetap II Bandung dilaksanakan pada 1 Februari 2019; Indonesia Timur diwakili Kodam XVI Pattimura/Garnisun Ambon dan Polda Maluku, berlangsung pada 11 Desember 2018; 
dan Indonesia Tengah diwakili Kodam XII Tanjungpura, Polda Kalimantan Barat, Lantamal XII Pontianak dan Lanud Supadio Pontianak pada 3 Mei 2019. Di pengujung FGD peserta diskusi sungguh meyakini bahwa dengan spirit kepemimpinan yang melayani (servant leadership) yang dihidupi oleh OCI dapat secara efektif mengelola konflik demi terwujudnya damai yang lestari.

\section{Diskusi (FGD) dengan Staf TNI dan Polri}

Tabel 1: Pengambilan Sampel Penelitian dalam kegiatan FGD:

\begin{tabular}{|l|l|l|}
\hline Lokasi & Tanggal & Banyak Partisipan \\
\hline Jakarta, Indonesia & 7 Desember 2018 & Staf pria: 33 \\
& & Staf wanita: 28 \\
\hline Ambon, Indonesia & 11 Desember 2018 & Staf pria: 23 \\
& & Staf wanita: 7 \\
\hline Bandung, Indonesia & 1 Februari 2019 & Staf pria: 25 \\
& & Staf wanita: 12 \\
\hline Pontianak Indonesia & 3 Mei 2019 & Staf pria: 26 \\
& & Staf wanita: 21 \\
\hline
\end{tabular}

Sumber: Wuli, Luddin, dan Suyatno (2020)

Untuk memperkaya hasil penelitian juga dilakukan wawancara khusus dan wawancara tertulis dengan beberapa narasumber diantaranya wawancara eksklusif dengan narasumber utama Uskup TNI-Polri Mgr. Prof. Dr. Ignatius Suharyo, wawancara khusus dengan Letkol Inf. Emilianus I Betekenen dari Kodam XVI Pattimura, Wakapolda Kalimantan Barat Brigjen Pol Sri Handayani dan Laksma TNI Gregorius Agung, Danlantamal XII Pontianak. Sedangkan wawancara tertulis di antaranya Letkol Caj Diana Gaudentia, Kolonel Inf. Antonius Adiputra Kartika dan RP. Serafin Danny Sanusi, OSC.

Untuk memastikan keabsahan historis, penelitian dilengkapi studi dokumen yang berkaitan dengan topik penelitian dan melakukan observasi kehidupan prajurit TNI/Polri beragama Katolik di daerah perbatasan seperti di Entikong, perbatasan antara Indonesia-Malaysia; di Mota ${ }^{e e}$ ain Atambua, perbatasan antara Indonesia-Timor Leste , dan di Sukow, perbatasan Indonesia-Papua New Guinea.

Data yang diperoleh peneliti dianalisis dengan teknik analisis data kualitatif Model Miles dan Huberman. Miles dan Huberman (1994) mengedepankan aktivitas dalam analisis data kualitatif dilakukan secara interaktif yang berlangsung secara terus menerus sampai tuntas. Kegiatan dalam analisis data setelah data terkumpul (data colleting), yakni reduksi data (data reduction), penyajian data (data display), dan kesimpulan /verifikasi (conclusion drawing/verification). 


\section{HASIL PENELITIAN DAN PEMBAHASAN}

\section{Profil Keuskupan TNI/Polri atau Ordinariatus Castrensis Indonesia (OCI)}

Berdasarkan tinjauan historis, Keuskupan Umat Katolik di Lingkungan TNI/Polri harus diawali dari Keuskupan Militer. Di Indonesia jejak reksa pastoral di kalangan militer dimulai tahun 1949, tepatnya 3 November 1949. Adalah Sri Sultan Hamengku Buwono IX, Menteri Pertahanan saat itu membentuk staf khusus yang bertugas menangani perawatan rohani tentara. Saat itu Indonesia sedang mengadakan diplomasi politik melawan Belanda, yang menolak mengakui kedaulatan Negara Indonesia yang diproklamirkan pada 17 Agustus 1945. Dalam situasi konflik tersebut, Tahta Suci Vatikan, melalui Surat Keputusan (Decretum) Kongregasi Suci untuk Pengembangan Iman (kini bernama Kongregasi Evangelisasi Bangsa-bangsa) Nomor 102/50 tertanggal 25 Desember 1949 secara resmi membentuk Keuskupan Militer di Indonesia (Latin: Ordinariatus Castrensis Indonesia - OCI). Surat Keputusan tersebut juga memuat tentang pengangkatan Mgr. Albertus Soegijapranata SJ sebagai Vicarius Castrensis (Uskup Militer) pertama di Indonesia.

Pendirian Keuskupan TNI/Polri merupakan diplomasi senyap (silent diplomacy) Mgr. Soegijapranata membuahkan hasil yang membanggakan. Vatikan menjadi salah satu negara pertama yang mengakui dan mendukung proklamasi kemerdekaan Republik Indonesia dan sekaligus membentuk Vikariat Militer di Indonesia (Neto Wuli, 2019: 18). Kini Keuskupan TNI/Polri dipimpin Mgr Prof. Dr. Ignatius Suharyo. Keuskupan Militer (OCI) tampil sebagai satu-satunya Keuskupan Kategorial yang tidak berdasarkan wilayah tertentu, tetapi khusus memberikan pelayanan dan pendampingan rohani serta mental kepada anggota TNI/Polri beragama Katolik di Indonesia. Karena tidak memiliki wilayah teritori, maka dalam menjalankan reksa pastoral bagi para prajurit TNI/Polri, Keuskupan Militer bekerja sama dengan pimpinan gereja lokal (uskup setempat).

Personalia atau tenaga pastoral di OCI terdiri dari seorang Uskup, sejumlah Pastor dan beberapa Katekis Militer/Polisi. Uskup TNI/Polri: Mgr. Ignatius Suharyo; Vikjen: RD.Yosef MM Bintoro; Pastor Pendamping TNI/Polri seluruh wilayah Indonesia (Pasbanmilpol): RD. Rofinus Neto Wuli; Pastor TNI AU aktif: RD.Yos Bintoro dan RD. Paulus Nasib; Pastor Purn TNI AL: RD. Suto Panitro, Pastor Pensiunan PNS TNI AL: RD. Albert Hendaryono, Pastor Pensiunan PNS AU: RD. Bernardus Harisusanto. Dalam keseluruhan pelaksanaan kegiatan sehari-hari dan program kerja tahunan, OCI melihat adanya kesejajaran antara status sebagai "warga Negara dan warga Agama," maka pemantapan spirit keimanan dan spirit kebangsaan prajurit terus menjadi prioritas karya pelayanannya. Dalam konteks ini hendak dikatakan bahwa profesi mereka sebagai anggota TNI/Polri, tidak terpisah dari perwujudan iman Kekatolikan. Nilai-nilai Katolik diinternalisasi kemudian diaktualisasi untuk dijadikan sebagai kekuatan merawat NKRI. Seperti para murid Yesus pertama, umat di Lingkungan TNI/Polri adalah pribadipribadi yang terpanggil dan terpilih untuk melayani.

Walaupun struktur organisasi OCI sangat longgar, namun terpola dalam praktik bentuk kemitraan antara OCI dan umat Katolik di institusi TNI/Polri dapat digambarkan sebagai berikut. 


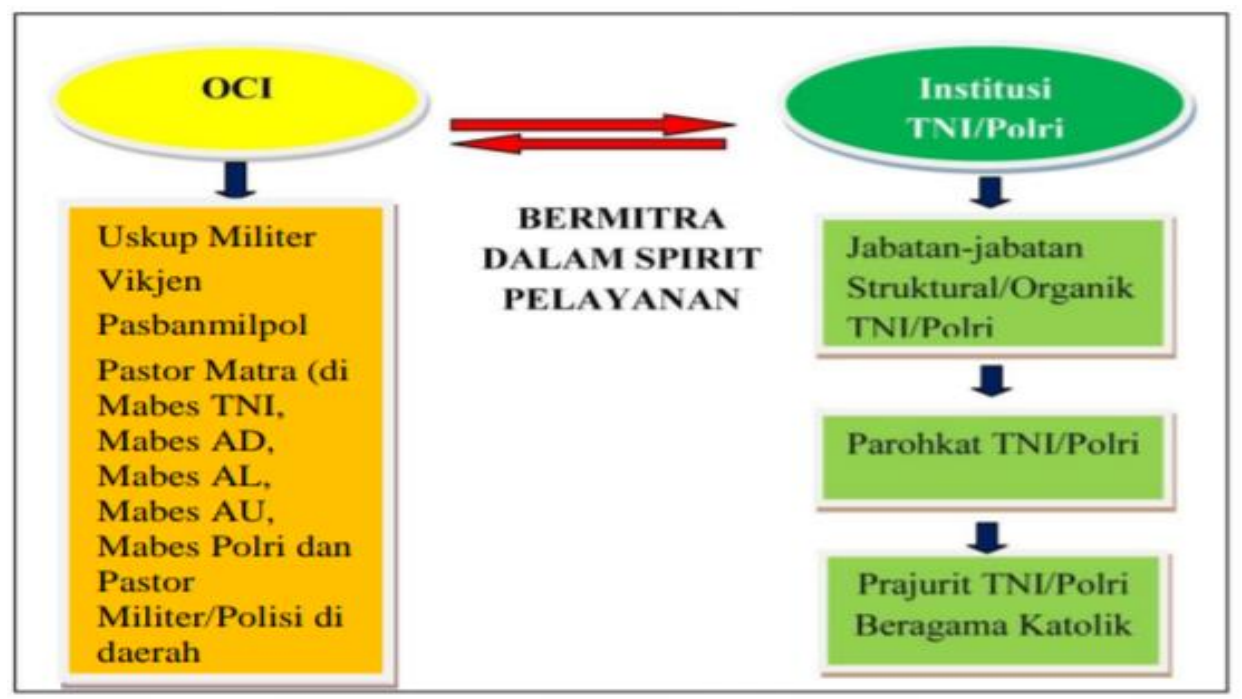

Gambar: Struktur Pelayanan Organisasi OCI Dalam Kemitraan Dengan Insitusi TNI/Polri

\section{Konflik dalam Perspektif Warga OCI}

Warga OCI memiliki perspektif tersendiri tentang konflik. Menurut mereka, konflik adalah keniscayaan dalam kehidupan manusia. Ditemukan beberapa klasifikasi konflik: konflik karena perbedaan pendapat, pandangan dan keyakinan; konflik berkaitan dengan profesi dan tugas prajurit di lapangan; konflik karena perbedaan minoritas dan mayoritas; konflik karena ujaran kebencian; dan konflik dalam rumah tangga. Ketika konflik bereskalasi kekerasan, maka konflik harus dikelola secara bijak melalui manajemen konflik.

Yang menarik, hampir semua narasumber mengakui tidak pernah mengalami konflik sebagai warga OCI. Bahkan mereka merasakan kehadiran OCI sebagai rumah besar yang memberi kehangatan, kasih, belarasa dan kepedulian, sehingga mereka merasa sebagai saudara. Mereka tidak mengalami konflik, tetapi justru merasakan teduh hidup damai. Mereka saling menyapa, saling meneguhkan dan saling membagi kasih sebagai saudara seiman. Memang ada perbedaan pendapat, terutama berkaitan dengan kepanitiaan untuk kegiatan keagamaan tertentu. Perbedaan pendapat seperti itu hal yang wajar untuk menyamakan persepsi dan tidak menimbulkan konflik berarti serta sangat mudah diselesaikan. Karena perbedaan pendapat justru semakin mematangkan sebuah rencana untuk hasil akhir yang memuaskan semua pihak.

Namun ada juga persoalan pribadi sebagai umat Katolik yang bernaung di bawah OCI. Persoalan tersebut biasanya sangat pribadi, yaitu berkaitan dengan konflik rumah tangga dan pindah agama/keyakinan. Konflik dalam rumah tangga sebenarnya hal yang biasa. Tidak ada manusia yang sempurna. Cinta kedua insan yang telah dipersatukan dalam Sakramen Perkawinan harus diperjuangkan terus-menerus. Yang menjadi masalah, jika konflik dalam rumah tangga berujung pada kekerasan dalam rumah tangga (KDRT) dan perceraian. Kehadiran OCI diharapkan dapat menolong keluarga yang bermasalah untuk mempertahankan keutuhan rumah tangga sebagai persemaian tumbuhnya generasi masa depan yang baik, sehat dan tangguh. 


\section{Spirit Pelayanan Umat Katolik di OCI dan TNI/Polri}

Spirit pelayanan yanng dimaksud adalah roh, semangat, atau kekuatan yang menggerakkan prajurit TNI/Polri di OCI dan institusi TNI/Polri untuk melakukan kepemimpinan yang melayani. Dalam konteks ini, spirit pelayanan umat Katolik di OCI membahas aspek kepemimpinan sebagai bagian penting yang tidak terpisahkan. Spirit pelayanan di OCI dan institusi TNI/Polri memiliki perbedaan motif karena memiliki pendekatan yang berbeda. Spirit pelayanan yang dihayati warga OCI bersumber pada nilai universal Kristiani seperti kasih, pelayanan, kelembutan, kebenaran, keadilan, damai sejahtera, harmoni, belarasa, dan solidaritas. Nilai-nilai ini secara efektif dapat ditransformasi anggota OCI dalam kehidupan bersama.

Secara umum ada pemahaman bahwa ada perbedaan tipe atau gaya kepemimpinan di institusi TNI/Polri dan organisasi OCI. Tipe atau gaya kepemimpinan yang diterapkan di institusi TNI/Polri adalah gaya kepemimpinan yang tegas dan kuat (strong leadership) dengan rantai komando yang jelas dan tegas. Sementara organisasi OCI menerapkan gaya kepemimpinan yang melayani (servant leadership).

Narasumber lebih mengapresiasi tipe atau gaya kepemimpinan yang melayani (servant leadership) yang diterapkan di OCI. Walaupun tidak ada jenjang kepangkatan dan struktur jabatan berjenjang dengan garis komando yang jelas, kepemimpinan yang melayani justru sangat mengesankan dan menginspirasi para prajurit beragama Katolik dan keluarganya yang bernaung di bawah OCI untuk benar-benar menjadi $100 \%$ Katolik dan $100 \%$ Indonesia.

Yang menonjol dari tipe atau gaya kepemimpinan yang melayani adalah kasih yang tulus untuk melayani. Kasih menjadi dasar dari seluruh karya pelayanan dan kepemimpinan Kristiani. Kasih yang tulus selalu memberi yang terbaik bagi orang lain dan tidak pernah mengharapkan balasan dalam bentuk pujian, balas jasa atau penghormatan. Dalamkasih ada kelemah-lembutan, kerendahan hati, kebenaran, keadilan, damai sejahtera, empati, belarasa dan menghargai martabat manusia sebagai citra Tuhan (imago Dei). Karena kasih seorang pemimpin bersedia melayani orang lain, bukan memerintah orang lain. Dia memberi dirinya secara total untuk kemajuan dan kebaikan orang lain atau organisasi yang dipimpinnya.

\section{Aplikasi Manajemen Konflik di OCI}

Warga OCI memiliki keistimewaan. Di satu sisi, warga OCI adalah para prajurit TNI/Polri yang tunduk pada institusi masing-masing, tetapi di sisi lain mereka berada di bawah naunganOCI. Karena itu, manajemen konflik yang diterapkan tentu disesuaikan dengan status mereka sebagai warga OCI. Kalau ada konflik, maka penyelesaian konflik di OCI harus berlandaskan ajaran Gereja dan menjunjung tinggi martabat manusia serta mempertimbangkan kepentingan yang lebih luas berdasarkan spirit pelayanan yang dikembangkan OCI, yaitu kasih dan penghargaan terhadap martabat manusia. Keduanya adalah nilai-nilai transenden yakni nilai-nilai universal yang dapat mengajak pihak yang berkonflik untuk meninggalkan kepentingannya sendiri (conflict of interest) terbuka pada keluasan berpikir dan bertindak untuk mencapai perdamaian.

Di sini ada perbedaan manajemen konflik di OCI dan institusi TNI/Polri. Di institusi TNI/Polri ada SOP berdasarkan garis komando dan peraturan perundang- 
undangan yang berlaku. Sedang di organisasi OCI merujuk pada ajaran Gereja, yaitu cinta kasih.

Tabel 2: Persamaan dan perbedaan manajemen konflik di Institusi TNI/Polri dan manajemen konflik di Organisasi OCI:

\begin{tabular}{|l|l|l|}
\hline & TNI/Polri & OCI \\
\hline Dasar & $\begin{array}{l}\text { UU No. 34 2004 tentang TNI. } \\
\text { UU RI No. 3 tentan Pertahanan } \\
\text { Negara. }\end{array}$ & $\begin{array}{l}\text { Kitab Suci. } \\
\text { Dokumen Gereja al. } \\
\text { Kitab Hukum Kanonik } \\
\text { dan Katekismus Gereja } \\
\text { Katolik. }\end{array}$ \\
\hline tentang Polri. & $\begin{array}{l}\text { Kompromi, negosiasi, mediasi, } \\
\text { kolaborasi, konsolidasi dsb, } \\
\text { sampai pada kekuatan senjata } \\
\text { yang mengepankan persatuan } \\
\text { dan kesatuan banga, stabilitas } \\
\text { dan pertahanan negara, dsb. }\end{array}$ & $\begin{array}{l}\text { Kompromi, negosiasi, } \\
\text { mediasi, kolaborasi, } \\
\text { kekuatan senjata dan } \\
\text { mengedepankan kasih } \\
\text { yang melayani. }\end{array}$ \\
\hline $\begin{array}{l}\text { Pengambil } \\
\text { keputusan }\end{array}$ & $\begin{array}{l}\text { Panglima, Komandan, } \\
\text { Direktur, Kepala dsb yang } \\
\text { berwenang. }\end{array}$ & Uskup TNI/Polri \\
\hline Pimpinan tertinggi & Panglima TNI/Kapolri. & Uskup TNI/Polri \\
\hline
\end{tabular}

Kekuatan Servant Leadership dalm Manajemen Konflik untuk Resolusi Konflik di OCI

Manajemen Konflik berbasis kepemimpinan pelayan sangat kuat pengaruhnya dalam meresolusi konflik karena digerakan oleh spirit Iman yang berkualifikasi melayani dalam damai. Kepemimpinan yang ideal dalam menyelesaikan konflik adalah kepemimpinan pelayan melalui pendekatan kemanusiaan yang diyakini dapat menghasilkan rekonsiliasi dan damai yang berkelanjutan.

Resolusi konflik di institusi TNI/Polri dan organisasi OCI memang berbeda. Di institusi TNI/Pori, resolusi konflik merujuk pada doktrin dengan rantai komando berjenjang. Setiap konflik yang terjadi dan melibatkan prajurit TNI/Polri biasanya diselesaikan oleh pimpinan atau komandan masing-masing kesatuan secara berjenjang. Prajurit yang terlibat dalam konflik terlebih dahulu diamankan untuk mencegah meluasnya konflik dan mempermudah proses penyelidikan dan penyidikan.

Dalam organisasi OCI, resolusi konflik lebih menekankan pendekatan kemanusiaan dengan semangat cinta kasih dan penghargaan terhadap martabat manusia. Dari hasil penelitian lapangan, para responden mengakui, bahwa resolusi konflik yang dikembangkan di organisasi OCI berpengaruh kuat menyelesaikan konflik. Para responden sepakat bahwa nilai-nilai Kristiani seperti cinta kasih, kelemah-lembutan, 
pelayanan, persaudaraan, belarasa dan solider menjadi faktor pembeda dalam proses resolusi konflik di organisasi OCI.

\section{Rekonsiliasi dan Damai Berkelanjutan di OCI}

Keuskupan TNI/Polri menegaskan akan mengeliminasi atau meniadakan konflik melalui manjemen konflik, yang mengarah pada resolusi konflik dan damai berkelanjutan. Resolusi konflik apapun bentuk dan pendekatannya harus mengarah pada proses rekonsiliasi, yaitu memulihkan kembali hubungan yang terganggu karena perbedaan pendapat, paham, kepentingan, ideologi atau pilihan politik dan kondisi sosial atau lingkungan kerja yang tidak kondusif. Dengan demikian, fokus dari proses resolusi konflik adalah upaya membangun kembali harmoni sosial dan hubungan baik di antara para pihak yang berkonflik.

Rekonsiliasi dan damai berkelanjutan dapat meniadakan konflik karena menggunakan pendekatan kemanusiaan yang bersifat transendental. OCI menekankan tentang perlunya mencari nilai-nilai transendental yang bisa menjadi ajang pertemuan dua pihak yang berkonflik. Nilai-nilai transendental adalah nilai-nilai moral universal yang mengatasi (melampaui) kepentingan dua pihakyang bertikai, seperti kasih, kemanusiaan, toleransi, saling menghargai, kebenaran, dan lain-lain.

\section{Kebaruan Penelitian : Dinamika Manajemen Konflik Berbasis Servant Leadership.}

Dari keseluruhan kegiatan penelitian mulai dari Observasi, Wawancara dan FGD dengan para prajurit, perwira, purnawiran dan PNS di lingkungan TNI/Polri beragama Katolik yang merupakan warga OCI ditemukan sebuah kebaruan (novelty). Kebaruan penelitian ini adalah bahwa kepemimpinan yang melayani (servant leadership) berdampak kuat dalam mengelola dan meresolusi konflik menuju terciptanya rekonsiliasi dan budaya damai berkelanjutan. Kebaruan penelitian ini terletak pada kepemimpinan pelayan dapat menjadi basis yang kuat dalam mengeliminasi konflik serta memiliki empat elemen utama yang sangat penting dan strategis dalam manajemen konflik yang bermuara pada rekonsiliasi damai. Melalui "Dinamika Manajemen Konflik Berbasis Servant Leadership", ditemukan empat tahapan mengelola dan meresolusi konflik (konflik dalam pengertian yang komprehensif dalam perspektif positive-peace-nya Johnn Galtung).

Bagan-bagan berikut ini menggambarkan dinamika elemen-elemen dasar dari servant leadership sebagai basis pengelolaan konflik menuju terciptanya rekonsiliasi dan damai berkelanjutan.

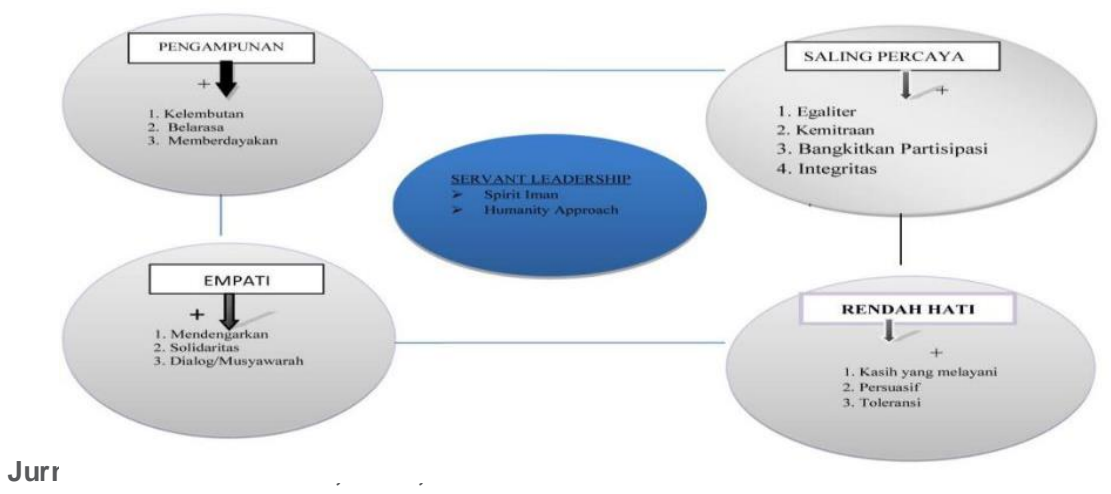


Gambar Bagan 1 : Elemen-elemen utama servant leadership berkekuatan positif (+) saling berhubungan dengan garis penghubung yang belum bertanda panah.

Bagan 1 menampilkan empat elemen utama: pengampunan, saling percaya, empati, dan rendah hati. Setiap elemen memiliki nilai-nilai utama sebagai bagian tidak terpisahkan. Dalam pengampunan terdapat kelembutan, belarasa, dan sikap memberdayakan. Dalam empati, terdapat sikap mendengarkan, solidaritas, dan dialog. Elemen rendah hati mencakup kasih yang melayani, sikap persuasif dan toleransi. Saling percaya dimungkinkan oleh spirit egaliter, kemitraan, partisipasi, dan integritas. Garis penghubung dalam Bagan 1 ini memaknakan keserentakan empat elemen tersebut di OCI. Artinya, empat elemen ini dilakukan serentak dan terus-menerus, berkesinambungan dalam OCI. Melalui observasi, wawancara dan FGD dengan para prajurit, perwira, purnawiran dan PNS di lingkungan TNI/Polri beragama Katolik yang merupakan warga OCI ditemukan empat elemen utama tersebut. Misalnya dalam wawancara Letkol Caj Gaudensia Diana pada 22 Desember 2018. Empat elemen ini tidak terpisah, tetapi memiliki kaitan erat satu sama yang lain.

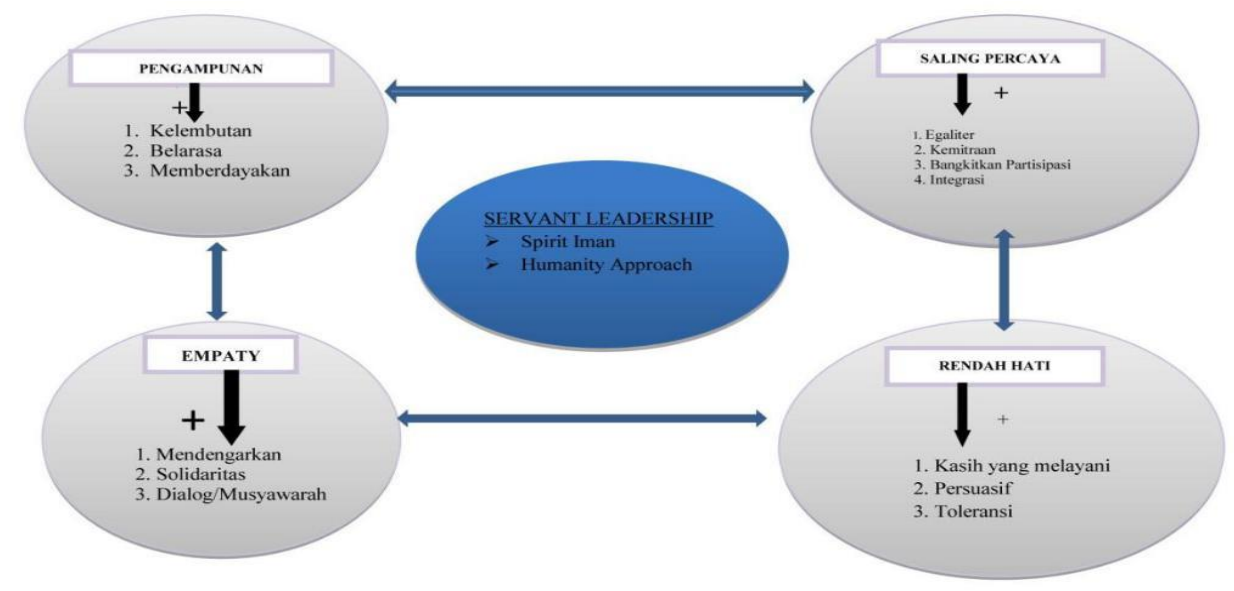

Gambar Bagan 2 : Empat elemen utama Servant Leadership berkekuatan positif saling berhubungan dengan garis penghubung yang sudahbertanda panah timbal balik.

Dalam Bagan 2 ini, keempat elemen utama tersebut tidak hanya berhubungan, tetapi saling berinteraksi, timbal-balik. Artinya, semua elemen serentak memiliki peran signifikan dan substansial. Elemen-elemen itu berada dalam posisi setara, sehingga saling membutuhkan, saling terbuka, saling mengisi, dan saling bekerja sama. Elemenelemen yang saling berinteraksi ini diwujudkan para prajurit TNI/Polri beragam Katolik yang tergabung dalam OCI. Seorang anggota menjalankan empat elemen utama tersebut. 


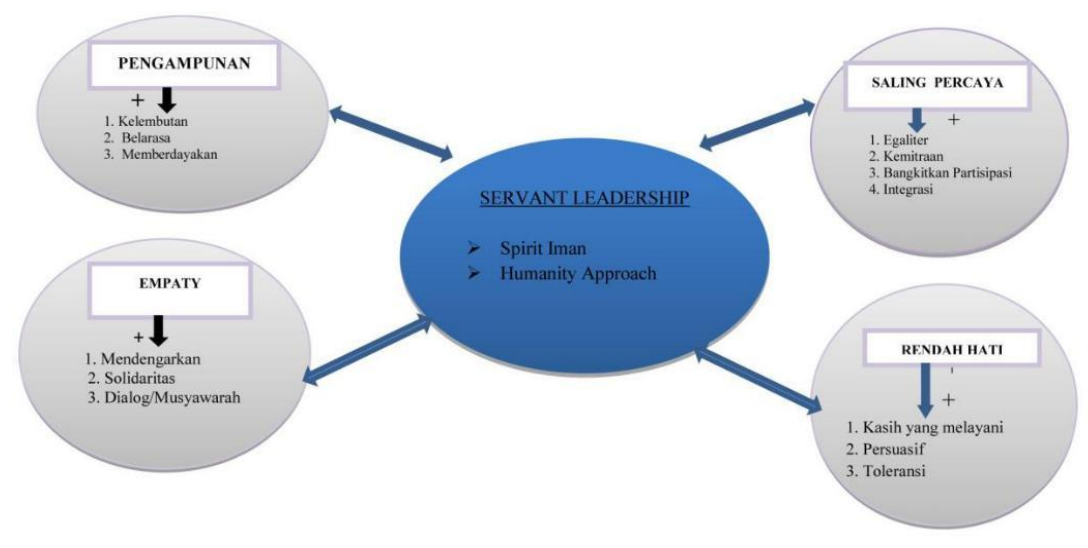

Gambar Bagan 3 : Empat elemen utama berkekuatan positif (+) terhubung timbal balik dengan supremasi Servant Leadership yang ditandai dengan ikatan panah tebal secara timbal balik.

Jika pada Bagan 2 terdapat hubungan timbal balik antara empat elemen, maka pada tahapan selanjutnya yang digambarkan dalam bagan 3 menunjukkan hubungan timbal balik yang menguntungkan antara kepemimpinan pelayan dengan empat elemen utama tersebut.

Pada tahapan ini hubungan timbal balik antara empat elemen membutuhkan peran kepemimpinan pelayan. Artinya, meskipun menjalin hubungan timbal balik positif, tetapi kepemimpinan pelayan juga mengikat empat elemen menjadi satu kesatuan yang utuh. Dalam observasi, wawancara, FGD ditemukan bahwa pemimpin yang menginspirasikan pengampunan, empati, saling percaya, dan rendah hati pada tingkat kematangan (kesempurnaan) dapat mengikat empat elemen tersebut sebagai satu kesatuan. Paus Fransiskus dan Uskup OCI Mgr. Suharyo menjadi role model pemimpin yang memiliki supremasi seperti ini. Didasari spirit keimanan Katolik, keduanya menerapkan pendekatan kemanusiaan dalam organisasi. Karena itu, supremasi bukan dalam pengertian kepemimpinan kuat yang menerapkan gaya komando. Supremasi dalam pengertian keteladanan pemimpin yang menerapkan nilainilai kemanusiaan seperti pengampunan, empati, rendah hati, dan saling percaya dalam hidup sehari-hari. Keteladanan ini menggerakkan anggota organisasi, bahkan pihak luar untuk menerapkan dalam kehidupan sehari-hari. Kepemimpinan pelayan dapat mengikat dan mengoperasionalisasikan empat elemen tersebut. 


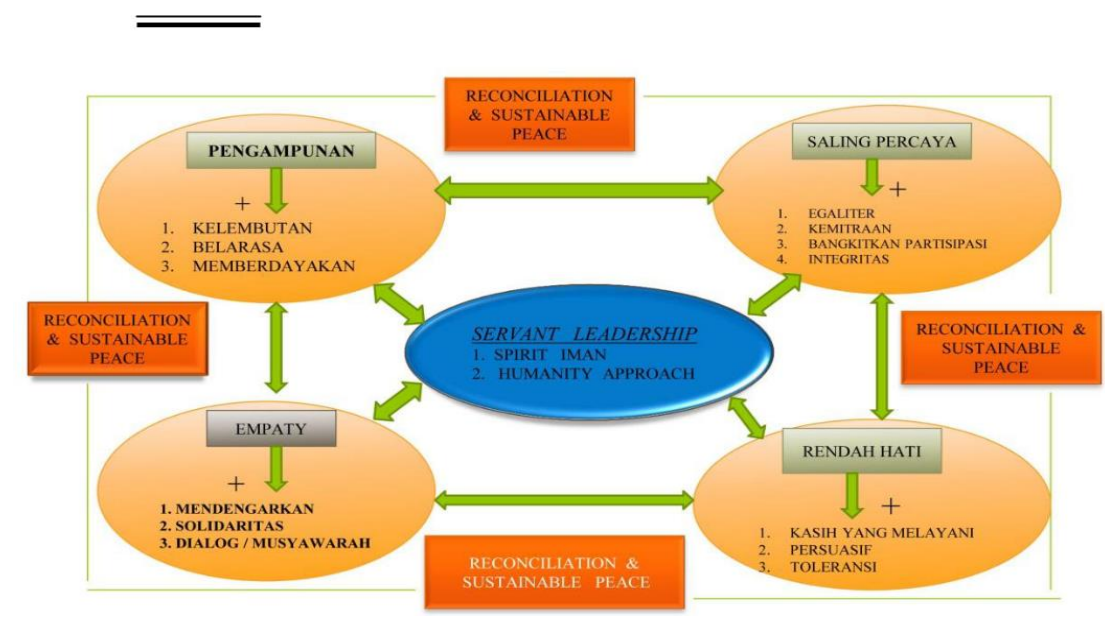

DINAMIKA MANAJEMEN KONFLIK BERBASIS SERVANT LEADERSHIP (Rofinus Neto Wuli, 2019)

Gambar Bagan 4 : Dinamika manajemen konflik berbasis servant leadership, empat elemen utama servant leadership berkekuatan positif (+) menjadi satu bagan utuh yang dibingkai satu kotak segi empat utuh menunjukkan reconciliation dan sustainable peace sebagai muara dari manajemen konflik.

\section{Keterangan :}

1. Kepemimpinan pelayan (servant leadership) adalah kepemimpinan yang menginspirasikan iman dan meneladankan pelayanan kemanusiaan yang berkekuatan pengampunan, saling percaya, empati, kerendahan hati dalam membantu orang berhasil baik secara profesional maupun individual. Servant leadership adalah kualitas kepemimpinan yang melayani dengan ikatan kuat yang saling berhubungan dari empat elemen utama yakni pengampunan (kelembutan, belarasa, memberdayakan), saling percaya (egaliter, kemitraan, partisipasi, integrasi), empati (mendengarkan, solidaritas, dialog/musyawarah), rendah hati (kasih yang melayani, persuasif, toleransi).

2. Manajemen konflik adalah mengelola dan meyelesaikan konflik yang terjadi dalam kehidupan manusia dengan berbasiskan empat elemen utama (pengampunan, saling percaya, empati, rendah hati) yang membentuk satu kesatuan dalam pengaruh kepribadian kuat seorang pemimpin pelayan (servant leader).

3. Hanya pemimpin pelayan dengan keutamaan servant leadership pada tingkat kematangan tertinggi (Paus, Uskup) yang mampu mengikat empat elemen utama menjadi satu kesatuan utuh secara efektif dapat mengelola dan me-resolusi konflik (Pope Francis as a model of servant leadership-Nancy Murphy (2015), Uskup OCI Mgr. Prof Dr. Ignatius Suharyo adalah role model seorang pemimpin pelayan yang rendah hati-Diana Gaudensia 2019).

4. Empat elemen utama servant leadership berkekuatan positif (+) akhirnya menjadi satu kesatuan utuh yang mewujudkan rekonsiliasi dan damai berkelanjutan (reconciliation and sustainable peace) sebagai muara dari manajemen dan resolusi konflik. 
Gambar Bagan 4 menunjukkan tahapan akhir dari dinamika manajemen konflik. Melalui observasi, wawancara, FGD, dan studi dokumen dapat disimpulkan bahwa kepemimpinan yang melayani dapat menjadi basis bagi manajemen dan resolusi konflik menuju terciptanya rekonsiliasi dan damai berkelanjutan. Dengan demikian melalui kerangka dinamis ini dapat ditemukan empat tahapan mengelola dan meresolusi konflik berdasarkan penelitian terhadap manajemen konflik berbasis kepemimpinan yang melayani di OCI (konflik yang dimaksud dalam pengertian komprehensif positive peace-nya John Galtung)).

Tahapan pertama, mengusahakan adanya nilai pengampunan (kelembutan, belarasa, memberdayakan), saling percaya (egaliter, kemitraan, partisipasi, integrasi), empati (mendengarkan, solidaritas, dialog/musyawarah), rendah hati (kasih yang melayani, persuasif, toleransi).

Tahapan kedua, pihak yang berkonflik (juga komunitas berbudaya damai) memastikan pengampunan, saling percaya, empati dan rendah hati dilakukan secara serentak, bekerja sama, dibiasakan menjadi habitus baru, dan dipraktikkan dalam hidup.

Tahapan ketiga, pihak yang berkonflik (juga komunitas berbudaya damai) menjalankan kepemimpinan yang melayani sebagai pengikat empat elemen tersebut. Pemimpin yang menjalankan kepemimpinan pelayan sangat diandalkan, karena melakukan pendekatan kemanusiaan. Teladan kepemimpinan yang melayani dapat menggerakkan pihak yang berkonflik (inspirasi dan teladan) untuk memiliki sikap pengampunan, saling percaya, rendah hati, dan memiliki empati.

Tahapan keempat, melakukan manajemen dan resolusi konflik berbasis kepemimpinan yang melayani. Empat elemen utama servant leadership berkekuatan positif (+) akhirnya menjadi satu kesatuan utuh yang mewujudkan rekonsiliasi dan damai berkelanjutan (reconciliation dan sustainable peace) sebagai muara dari manajemen dan resolusi konflik. Dikatakan dinamika manajemen konflik karena elemen-elemen utama servant leadership bergerak dinamis mengikuti kekuatan kepemimpinan yang melayani. Elemen-elemen tidak kaku, atau statis. Artinya, semakin matang dan semakin tinggi pelayanan seorang pemimpin, maka semakin mengikat, mempengaruhi, dan menggerakkan elemen-elemen tersebut. Selain itu, empat elemen tersebut mengalami dinamika dalam tahapan operasionalnya tergantung dari konteks konflik dan penerapan konkret kepemimpinan yang melayani sebagai basis manajemen konflik. Misalnya, dalam konteks konflik A yang belum bereskalasi kekerasan, maka elemen rendah hati yang dikedepankan, pengampunan dan empati, serta saling percaya mendukung di belakang elemen rendah hati. Pada konflik B di mana telah terjadi eskalasi kekerasan, maka elemen pengampunan atau pemaafan perlu didahulukan dari elemen yang lainnya. Elemen-elemen tersebut terus bergerak dinamis sesuai konteks konflik yang dihadapi.

\section{KESIMPULAN}

1. Dalam perspektif warga Keuskupan TNI/Polri atau Ordinariatus Castrensis Indonesia (OCI), konflik adalah sebuah keniscayaan di dalam kehidupan manusia. Ditemukan beberapa klasifikasi konflik, yaitu: a) karena perbedaan pendapat, pandangan dan keyakinan; b) yang berkaitan dengan profesi dan tugas prajurit di lapangan; c) karena perbedaan minoritas dan mayoritas; d) karena ujaran kebencian; dan e) dalam rumah tangga. Konflik-konflik ini berpotensi menimbulkan kekerasan, 
maka konflik harus dikelola secara bijak melalui manajemen konflik. Dalam manajemen konflik ada resolusi konflik, sebuah metode yang dianggap efektif untuk menyelesaikan konflik berbasis pendekatan kemanusiaan.

2. Spirit pelayanan yang yang dihayati warga Keuskupan TNI/Polri atau Ordinariatus Castrensis Indonesia (OCI) bersumber pada nilai-nilai Kristiani seperti kasih, pelayanan, kelembutan, kebenaran, keadilan, damai sejahtera, mendengarkan, memberdayakan, harmoni, belarasa, dan solidaritas sosial (Markus 10: 42-44 dan Matius 20: 25-28). Nilai-nilai ini ternyata secara efektif dapat ditransformasi anggota Keuskupan TNI/Polri atau Ordinariatus Castrensis Indonesia (OCI) dalam kehidupan bersama. OCI sangat mengedepankan adanya "kewajiban pelayanan". Berbeda dengan institusi TNI/Polri, dengan pendekatan manajemen konflik merujuk pada SOP dengan sistem komando berdasarkan undang-undang yang berlaku dan pedoman hidup prajurit TNI/Polri yang tertuang dalam Sapta Marga, Sumpah Prajurit dan Tri Brata.

3. Penerapan manajemen konflik di Keuskupan TNI/Polri atau Ordinariatus Castrensis Indonesia (OCI) merujuk pada ajaran Gereja Katolik yang menempatkan hukum cinta/kasih dan pengampunan (forgiveness) sebagai utama.

4. Manajemen konflik berbasis kepemimpinan yang melayani (servant leadership) sangat kuat dan efektif dalam mengelola dan meresolusi konflik. Kepemimpinan dalam Keuskupan TNI/Polri atau Ordinariatus Castrensis Indonesia (OCI) berkualifikasi melayani satu sama lain, untuk memperjuangan terciptanya perdamaian. Manajemen konflik untuk mencapai perdamaian menjadi basis sekaligus tujuan dari kepemimpinan yang melayani. Melalui pendekatan kemanusiaan, manajemen konflik berbasis kepemimpinan yang melayani menggunakan nilai-nilai transedental agama.

5. Kepemimpinan pelayan (servant leadership) dapat menjadi basis yang kuat dalam mengeliminir konflik serta memiliki elemen-elemen utama yang sangat penting dan strategis dalam manajemen dan resolusi konflik yang bermuara pada rekonsiliasi dan damai berkelanjutan. Melalui "Dinamika Manajemen Konflik Berbasis Servant Leadership," ditemukan empat tahapan megelola dan meresolusi konflik (konflik dalam pengertian komprehensif positive peace-nya John Galtung). Tahapan pertama, mengusahakan adanya nilai saling percaya (trust), pengampunan (forgiveness), empati (empathy), dan kerendahan hati (humility) dari pihak yang berkonflik (ataupun dalam organisasi yang sudah berbudaya damai). Ada empat elemen utama servant leadership itu adalah pengampunan (yang meliputi: kelembutan, belarasa, memberdayakan), saling percaya (yang meliputi: egaliter, kemitraan, partisipasi, integrasi), empati (yang meliputi: mendengarkan, solidaritas, dialog/musyawarah), rendah hati (yang meliputi: kasih yang melayani, persuasif, toleransi). Tahapan kedua, pihak yang berkonflik (juga komunitas berbudaya damai) memastikan pengampunan, saling percaya, empati dan rendah hati dilakukan secara serentak, bekerja sama, dibiasakan, dan dipraktikkan dalam hidup sehari-hari. Tahapan ketiga, pihak yang berkonflik (komunitas berbudaya damai) menjalankan 
kepemimpinan yang melayani sebagai pengikat empat elemen tersebut. Pemimpin yang menjalankan kepemimpinan pelayan sangat diandalkan, karena melakukan pendekatan kemanusiaan. Teladan kepemimpinan yang melayani dapat menggerakkan pihak yang berkonflik (inspirasi dan teladan) untuk memiliki sikap pengampunan, saling percaya, rendah hati, dan memiliki empati. Tahapan keempat, melakukan manajemen dan resolusi konflik berbasis kepemimpinan yang melayani. Empat elemen utama servant leadership berkekuatan positif (+) akhirnya menjadi satu kesatuan utuh yang mewujudkan rekonsiliasi dan damai berkelanjutan (reconciliation and sustainable peace) sebagai muara dari Manajemen dan Resolusi Konflik. Rekonsiliasi dan damai yang terwujud lahir dari refleksi nurani para pihak yang berkonflik, bahwa sebagai sesama ciptaan Tuhan manusia harus hidup rukun, toleran dan damai. Damai yang terwujud bersifat abadi, tetap, atau berkelanjutan, bukan damai yang semu. Ada alasan transendental yang kuat untuk berdamai satu sama lain sebagai wujud damai dengan Tuhan Sang Pencipta.

\section{DAFTAR PUSTAKA}

Blake, R., \& Mouton, J. (1964). The Managerial Grid: The Key to Leadership Excellence. Houston, TX: Gulf Publishing Company.

Blanchard, Ken\& Broadwell, Renee. (2018). Servant Leadership in Action: How You Can Achieve Great Relationshpis and Results. Oakland CA:Berrett-Koehler Publishers.

(2019). Servant Leadership in Action:Kepemimpinan yang Memberdayakan dan Mengutamakan Orang (Terj. Diana Angelia). Jakarta: BPK Gunung Mulia. (2013).

Cinar, Fadima \& Ayca, Caban. (2012). "Conflict Management and Visionary Leadership: An Application in Hospital Organizations dalam Procecia - Social and Behavioral Sciences 58.

Creswell, John W. (2012). Research Design Pendekatan Kualitatif, Kuantitatif dan Mixed (terj. Achmad Fawaid). Yogyakarta: Pustaka Pelajar.

Dinas Pembinaan Mental Angkatan Darat, (2012). Bintal Fungsi Komando. Jakarta: Mabesad.

Fahmi, Irham (2016). Pengantar Sumber Daya Manusia: Konsep dan Kinerja. Jakarta: Mitra Wacana Media.

Galtung, Johan. (1996). Peace by Peaceful Means: Peace and Conclict, Development and Civilization. Oslo: Internasional Peace Research Institute.

. (2007). "Peace by Peaceful Conflict Transformation-the Trascend Approach" dalam Handbook of Peace and Conflict Studies, edited by Charles Webel \& Johan Galtung. Rouledge: USA. 
Ganta, V. C. and Manukonda, J. K. (2014). Leadership During Change And Uncertainty In Organizations. International Journal of Organiza-tional Behaviour \& Management Perspectives.

Geiko Muller-Fahrenholz. (2002).Rekonsiliasi: Upaya memecahkan Spiral

Kekerasandalam Masyarakat. Maumere: Penerbit Ledalero.

Greenleaf, Robert K. (1977). Servant Leadership: A Journey in to the Nature of Legitimate Power and Greatness, New York: Paulist Press. (2005).Servant As A Leader.USA: Carol Smith.

Habermas, Jürgen. (1993). Justification and Application: Remarks on Discourse Ethics. Cambridge, MA: MIT Press.

Kazimoto, Paluku. (2001). "Analysis of Conflict Management and Leadership For Organizational Change" dalam International Journal of Research In Social Sciences 3. Vol. 3, No.1, Sept.

Konferensi Waligereja Indonesia. (2018). Panggilan Gereja Dalam Hidup Berbangsa:Nota Pastoral KWI 2018. Jakarta: Penerbit Obor.

Konferensi Waligereja Indonesia. 2001. Membangun Budaya Adil dan Damai, Jakarta: Komisi Keadilan dan Perdamaian KWI.

Lederach, J.P(1997). Building Peace: Sustainable Reconciliation in Divided Societies. Washintong DC: Institute of Peace.

Miles, M.B., \& Huberman, A.M.(1994). QualitativeData analysis: And Sourcebook $2^{\text {nd }} \quad$ Edition. SAGE Publication, Inc.

expanded

Military Ordinariate, https://en.m.wikipedia.org

Murphy, Nancy. (2015). Pope Francis as a Model of Servant Leadership. https://www.linkedin.com October 5.

NetoWuli, Rofinus. (2019). Spirit Kebangsaan Prajurit Dalam Perspektif Spirituali Militum Curae. Jakarta: Penerbit Obor.

Neto Wuli, Rofinus. (2019). Conflict Resolution Toward a Sustainable Peace: A Lesson from The Indonesia Military Ordinariate" in International Journal of Human Resource Studies (IJHR S), ISSN 2016-3058, 2019, Vol. 9, No. 3, Aug. 15, 2019.

Neto Wuli, Rofinus. (2015). “Kekuatan Budaya dan Nilai-Nilai Keagamaan dalam Resolusi Konflik Demi Terwujudnya Rekonsiliasi dan Budaya Damai: Studi pada Masyarakat Ngada di Flores, Nusa TenggaraTimur (Tesis). Bogor: Unhan.

Neto Wuli, Rofinus, Luddin, Muchlis R, Suyatno, Thomas. (2020). "Servant Leadership to Manage Conflict: Case Study of the Indonesian Military Ordinariate", dalam Organizational Culturers: An International Journal (ISSN: 2327-8013, Vol. 20, Issue 1, 2020). 
Numberi,Freddy. (2011). Kepemimpinan Sepanjang Zaman. Jakarta: Bhuana Ilmu PopulerOrdinariat Militer Indonesia, https://id.m.wikipedia.org

Paulus II, Yohanes. (1986).Constitutio Apostolica Spirituali Militum Curae, Vatikan.

Program PascasarjanaUniversitas Negeri Jakarta. (2018). Pedoman Penulisan Karya Ilmiah. Jakarta: UNJ.

Susanto, AB. (2020). Handbook of Servant Leadership. Jakarta: The Jakarta Consulting Group.

Takore, Digvijaysinh. (2013). "Conflict and Conflict Management", dalam IOSR Journal of Business and Management.

Yukl, G. (2006). Leadership in Organizations (6th ed). Upper Saddle River, NJ: Pearson-Prentice Hall.

Thomas \& Ralp H. Kilmann (1974). The Thomas Kilmann Conflict Mode Instrument (Mountain View, CA: CPP, Inc).

Wirawan, (2009). Konflik dan Manajemen Konflik. Jakarta: Salemba Humanika. 